\title{
IDENTITY OF THREE BULGARIAN CHRISTIAN COMMUNITIES IN SOFIA
}

\author{
Rasa Račiūnaitè-Paužuoliené \\ An Associate Professor at the Department of Cultural Studies, Vytautas Magnus \\ University, Kaunas, Lithuania \\ e-mail: rasa.raciunaite-pauzuoliene@vdu.lt
}

First of all, we are Bulgarians, then Christians, and as such we break up into Orthodox and Catholics (city-dweller of Sofia)

\begin{abstract}
This article focuses on the history and identity of three Bulgarian Christian communities from the second part of 20th c. until today. The article presents the results of ethnographic explorations between 2010 and 2020 carried out on a comparative basis among three Bulgarian Christian denominations in Sofia. The case of the Bulgarian Orthodox Church shows that believers might be desrcibed as 'believing and belonging, without behaving' (PRC 2017b). Under the Soviet regime, members of the Bulgarian Catholic Church managed to maintain their religious identity due to their interconfessional links. Their religious identity was strengthened by their witnessing repressed priests, monks and selfless members of the laity. Modern Bulgarian Christians have multiple identities, but prioritize their ethnic identity, followed respectively by their identities as religious in general terms and finally specific confessional identities.
\end{abstract}

Keywords: Bulgarian Christian denominations, Othodox, Unitarians, Roman Catholics, religious identity, Sofia. 


\section{Introduction}

Religious life in post-socialist regions differs from that in Western Europe because of the unique historical, political, socio-cultural and economic situations in those regions. Post-socialist religious life has its own peculiarities in Bulgaria. Although the Church was formally separated from the state, religious life was persecuted, and religious rituals were prohibited under Bulgaria's Soviet-style totalitarian regime. Different Christian communities became sites of religious and cultural resistance against oppressive regimes in eastern Europe before the collapse of the Iron Curtain. Bulgarian Christian communities were no exception.

In Soviet-era Bulgaria, the state's relations with the various religions in the country depended on the unique historical situation, political regime, statesupported atheism, and local traditions. The totalitarian regime was negatively disposed towards religious communities and more or less mistreated all religious denominations. Their treatment depended on the status of the church-goers: they were treated as 'national', as was the case for the Bulgarian Orthodox Church, or 'international' (Ballinger andGhodsee 2011). Religion mainly depended on the ethnic and national identities of the Bulgarian people. According to Petar Kanev, being Bulgarian and being Orthodox might be treated as synonymous in Bulgaria due to the fact that Orthodoxy is often comprehended not as a religion but as a national and cultural identity (Kanev 2002: 84, 78), as other researchers have also argued. As Kristen Ghodsee maintains in her survey, Many Bulgarians 'believe that to change religious affiliation is to change ethnic and cultural identification' (Ghodsee 2009: 234). James Lindsay Hopkins points out that the Bulgarian Orthodox Church is a marker of national and ethnic identity, having become 'an instrument of Bulgarian geopolitism, allowing itself to get used by the government, as a necessary medium toward the realisation of its goal of national unification' (Hopkins 2008: 8). According to K. Ghodsee, Orthodoxy is closely linked to religious and national identity due to it being embedded in Church dogma (Ghodsee 2009: 235). When speaking about the relationship between the modern Bulgarian Orthodox Church and the state, she uses the concept of 'symphonic secularism, which she explains as follows:

Symphoneia (symphony) refers to the Eastern Orthodox doctrine that asserts that the spiritual authority of the Church should not take precedence over the temporal authority of the state, but rather that they should work together for the common good. (Ghodsee 2009: 228) 
In this context, religion is understood as a tool through which Tsars, Sultans, politburos or prime ministers have consolidated their power over ethnically or linguistically diverse populations, by promoting national identity through a church (or a mosque or synagogue) that instills loyalty to the state as part of its ecumenical dogma while also granting autonomy to other religiously defined communities. (Ghodsee 2009: 242)

Today the majority of people living in Bulgaria consider being Orthodox a significant component of their individual and national identity. According to a PRC survey (PRC 2017b), 75 per cent of respondents in Bulgaria identify as Orthodox, 15 per cent say they are Muslims, 5 per cent of participants identify as unaffilliated, 4 per cent of respondents identify as other, and only about 1 per cent as Catholics (PRC 2017b). Bulgarians, who are therefore mainly Orthodox, come third in the strength of religious beliefs in eastern Europe after Poles and Slovaks (50 per cent of Bulgarians never doubt God's existence) (PE 1991: 192). Nevertheless, the neo-secularization of Bulgarian society has inevitably marked the lives of many Bulgarian Christians, especially in the past decade. The process of secularization, 'related to globalization and neoliberal paradigm, reinforces and perpetuates the prevalence of individualistic discursive practices' (Merdjanova 2021, cited in Slavov 2020: 19). In Western Europe, secularization is linked to the process of 'believing without belonging', where widespread belief in God coexists with largely empty churches and the legal regulation of religious institutions (Davie 1994). This process is related to recent changes in Western Europe ('the change from a culture of obligation to the local parish, church, or denomination to consumption in terms of religious life') (Davie 2005, cited in Liu 2005) or the process 'neither believing nor belonging' (Voas and Crockett 2005). According to a Pew Reseach Center survey, Orthodox Christians in Central and Eastern Europe are more likely to believe in God and identify with Orthodox Christianity than practice their religion (PRC 2017b). They do not perform religious practices at high levels, such as daily prayers, regularly attending church and services of worship service, so they might be described as 'believing and belonging, without behaving' (ibid.).

In recent decades, Bulgarian Christians and their religious, national and cultural identities have become a subject of increased interest. A number of surveys have been carried out on the historical, sociocultural, political and religious aspects of Bulgarian Christians (Eldărov 1998, 2002; Slavov 2020; 
Serafimova 2011; Ballinger and Ghodsee 2011; Hopkins 2008; Ghodsee 2009; Hafkes-Teeples 2008; Roberson 2008; Brown 1983; Koinova 1999a; Kanev 2002; Kalkandjieva 2011, 2014; Eade 2012; Račiūnaitė-Paužuolienè 2018), local varieties of the family and calendrical feasts of Bulgarian Catholics and Orthodox Christians (Boncheva 2005; Jankov 2003; Račiūnaitė-Paužuolienė 2011; Lyubenova 2018; Paukštytè-Šaknienè 2019), the local treatment of religion as ban on marriage in light of its role as a key marker in constituting community identity (Boncheva 2006), and the distinctivness of the musical culture and national identity of Bulgarian Catholics (Grozdew 2004).

This article makes use of certain statistical sources related to Bulgarian Christians' religious issues, such as the Population Census 2011 (NSI 2011), prepared by National Statistical Institute, and The Eastern Catholic Churches Statistics (ECCS 2017), compiled by Ronald G. Roberson. Two sources should be distinguished from the professionally prepared statistics, namely two reports produced by the Pew Reseach Center (PRC). Both reports are part of the PewTempleton Global Religious Futures project. The first report, 'Religious Belief and National Belonging in Central and Eastern Europe' (PRC 2017b), analyzes religious change and its impact on societies around the world. Fieldwork for the survey was carried out by Ipsos MORI and the Institute for Comparative Social Research in Bulgaria in 2015. Following fieldwork, the survey's performance was assessed by comparing the results for key demographic variables with reliable, national-level population statistics. The second report, 'Orthodox Christianity in the 21st Century' (PRC 2017a), analyses religious change and its impact on societies around the world. It also brings together analyses of survey and demographic data from various previously published PRC reports. It also includes new analysis of the religious beliefs and practices of Orthodox Christians and historical data on the distribution of Orthodox Christians, Catholics and Protestants around the world.

\section{Methodology of the research}

The aim of this paper is to define the identity of three Bulgarian Christian communities in Sofia: the Bulgarian Orthodox Church, the Catholic Church of the Byzantine tradition, and the Roman Catholic Church. The article is broken down into three case studies, respectively of the Holy Trinity Bulgarian Orthodox Church, St. Joseph's Roman Catholic Church, and a Catholic church of the Byzantine rite, the Cathedral of the Assumption of the Blessed Virgin Mary. 
The study presents the identity of Bulgarian Christians covering the period of the second part of the 20th century and the second decade of the 21st century. The paper explores the problem of religious identity and its representation related to the experiences of these three religious denominations of Bulgarian Christians, including inter-faith relations among them. The paper focuses on the way Bulgarian Christians construct their identity. It asks the following questions: why do the members of different religious groups join their communities, and what do their religious identity and its representations consist of?

Although I have been exploring Bulgarian culture and religion for over a decade, the research for the present article is based on ethnographic fieldwork carried out in 2019-2021 as part of the bilateral international project on Festival and Everyday Culture in Bulgaria and Lithuania, as well as previous ethnographic fieldwork carried out in 2010-2012 and 2015-2017 as part of bilateral international projects co-funded by the Bulgarian and Lithuanian Academy of Science.

As just noted, this paper presents the results of comparative research carried out into three communities of Bulgarian Christians, all residents of Sofia. The research sample was broken down by gender (19 females and 21 males), age (age range from 26 to 80 ) and different social strata. The survey was administered face to face in public spaces such as parks, mountains, churches, pilgrimage sites and respondents' workplaces.

The ethnographic material was collected by the author using anthropological fieldwork methods, such as structured and semi-structured interviews, discussions, informal conversations and methods of observation. I conducted a total of forty interviews also held informal conversations with people from various social strata: the Christian laity, priests, monks, nuns, Christian religious leaders, government officials in charge of religious denominations, scholars and politicians. The questionnaire was prepared in English and Russian. The respondents answered to my questions in English, Russian, Polish and sometimes Bulgarian.

Interviews are one of the most important methods in conducting ethnographic fieldwork. According to John Monaghan and Peter Just, interviews can range in formality from highly structured question-and-answer sessions 'to the recording of life histories, to informal conversations, or to a chance exchange during an unanticipated encounter' (Monaghan and Just 2000: 23). Such informal conversations help the researcher to understand not just the usual ideas, but also informal types of knowledge. In addition, they help uncover the whole 
of a particular culture and the interconnectedness of social life. Thus, 'the key of ethnographic success is being there, available to observe, available to follow, available to take advantage of the chance event' (ibid.: 24), available to hear and understand both the usual ideas and informal knowledge.

Christianity in contemporary Bulgaria manifests itself in different denominations. In the following subsections I will present three Christian denominations: Bulgarian Orthodoxy, Roman Catholics of the Latin tradition and Bulgarian Catholics of the Byzantine tradition. Each of these churches has its own distinctive traditions of liturgy, rituals and devotions, though some of their respective traditions, rituals and prayers overlap.

\section{The Bulgarian Orthodox Church}

The first object of my reserch is the Bulgarian Orthodox Church, the oldest Slavonic Orthodox Church. It is also a local autocephal (independent) church that is in canonical unity, prayer and eucharistic communion with the other Orthodox Churches (BOC 2020a).

Historically, Orthodox Christianity dates to the ninth century in the Slavonic-speaking areas of eastern Europe. According to church tradition, two Byzantine missionaries, the brothers Cyril and Methodius from Constantinople, spread Christian faith in Europe. Orthodoxy came first to Bulgaria, Serbia and Moravia, and later, beginning in the tenth century, to Russia (PER 2017a). 'Following the Great Schism between the Eastern (Orthodox) churches and the Western (Catholic) church in 1054, Orthodox missionary activity expanded across the Russian Empire from the 1300s... (PER 2017a).

In 864 the Bulgarian Tsar Boris I was baptised and proclaimed Christianity the national religion (Dimitrov 2002: 14). The Bulgarian language became the official language of the Church and state at the end of the ninth century (BOC 2020b). At first, the Bulgarian patriarch recognized the authority of both the Roman Pope and the patriarch of Constantinople. Later, during the Ottoman era, the Church was placed under the latter's jurisdiction.

The Bulgarian Orthodox Church is in agreement with other Eastern Orthodox Churches. Eastern Orthodox theology is strongly Trinitarian: it states that God exists in the three persons of the Father, the Son and the Holy Spirit. The liturgy of the Othodox church represents one of the most significant factors in the church's continuity, identity and religious knowledge. Divine worship in the Bulgarian Orthodox Church includes a variety of symbols, using 'formal 
theological statements as well as bodily perceptions and gestures (e.g., music, incense, prostrations) and the visual arts' (Meyendorff 2020). The liturgy covers the total experience of believers and appeals to their emotional, aesthetic and intellectual dimensions. The Bulgarian Orthodox Church also has a very rich history of icons, which often depict Biblical scenes, Christian saints, the Virgin Mary or her son Jesus. The icons are seen as the dwelling places of God's grace, creating in the faithful a sense of the presence of God. In addition, many of the Church's calendar feasts are represented iconographically.

During the Soviet era the Church's property was confiscated by the state. In 1991, after the fall of the totalitarian regime, the Bulgarian Constitution designated Eastern Orthodox Christianity as the 'traditional' religion of the country (Roberson 2008). In 1997 the first Bulgarian Orthodox general council addressed the new possibilities that had opened to the Church in the new circumstances of a democratic society. It asked the Bulgarian goverment to guarantee religious instruction in schools, to return property confiscated by the Soviet-era regime and 'to begin a process of renewal of church life, including the development of catechetical programs and theological formation, the setting up of a large program of social action, the strengthening of the role of laity in Church, and the renewal of monasticism' (Roberson 2008).

In 2020 the Bulgarian Orthodox Church had thirteen local and two foreign dioceses, with about 2600 parishes attended to by 1500 priests. In addition, there were about 120 monasteries with 400 monks and nuns (VLE 2020). According to the statistics of the 2011 national census of the Bulgarian Republic, 4,374,135 citizens (about 60 per cent) of Bulgaria's total of 7,364,570 declared their religion as Eastern Orhodox Christianity (NSI 2011). However, only about 10 per cent of them regularly attend religious services or actively practice their religion. Other sources indicate that about 40 per cent of the Bulgarian population is atheistic or agnostic (Roberson 2008).

I now focus on the Bulgarian Orthodox church of the Holy Trinity (Xpam Света Троица) in Sofia, which is situated in the residential district of that name (see Fig. 1). It is a highly peopled parish served by four priests. This Bulgarian Orthodox church is known for its concerts of religious music, which are constantly being held there. One of the priests is a composer of Orthodox chants, thus keeping the culture of religious music alive there. Children are introduced to musical culture by means of socializing. Parish children are able to attend piano classes for free, a piano having been bought for that purpose. 
The parish of Holy Trinity also organizes excursions to different monasteries and holds educational classes.

The Holy Trinity church recalls the history of the parish. The last wave of Bulgarian refugees settled down in the region of the church in 1920. They had come from the city of Gevgelija, on the frontier between Macedonia and Greece. In their hometown they had had a Holy Trinity church and decided to rebuild it in their new place of residence in Sofia. The local authorities assigned them a plot of land, where they built a temporary church which started functioning in 1928. With time the former name of the district, Rasadnik, was changed to 'Holy Trinity'. The local people remember that in the beginning the temporary church had no tower, no pillars and no bell tower. Later, after 1960 a tower was built and in 1969 a colonnade was attached to it.

Many residents of the district had come from southwest Bulgaria, where people were very religious and nourished a deep veneration of St. Clement. According to the priest of the church, it was there that the first spiritual seminary in Europe was established (III/22). Old religious traditions that worshippers continued nourishing in the newly founded parish are still alive there today. Those who came to live in the district contributed to strengthening Christianity.

The priest pointed out that the believers who settled there in about 1960 have retained the old tradition of religiosity. 'Even their children and grandchildren stop playing football when they see a priest - they approach him and kiss his hand. After the spiritual father blesses them, they continue playing' (III/22).

The Orthodox priest noted that the residents of the district are not rich, but they have retained their living faith. Their religiosity has also had influence on other people. He remembered the case of a Macedonian woman who went to live to the USA and a short time later sent US $\$ 10,000$ to support her parish. He shared his own experiences as follows:

... about the year 1950, no one went to church in my native northwestern Bulgarian village, while in this parish people are used to baptising their children and getting married [in church]. Sometimes the only inscription in the book of [baptismal] registration is the name 'Mary', with no second names: in this way, the parents of the baptised child escaped state repression. In Soviet times there were a few rare weddings when newly-weds used to go to monasteries and secretly get married there. (III/22) 
The Orthodox priest who worked in the parish as a choir leader and a composer confessed that motive for entering the seminary was his desire to become not a priest but a conductor (III/21). While still young he was fascinated by the personality of Roberto Bianchi, which induced him to become a conductor. After the seminary he continued his studies in the spiritual academy of St. Clement. Then he worked as the conductor of a youth orchestra in Sofia and in 1985 returned back to the priesthood, at the same time working as the leader of the church choir. He recalls his path to the priesthood by saying:

I worked as a musician for 35-36 years and had no close ties with the Church. Then I decided to read the whole New Testament for the first time. The image of Christ emerged in its greatness before my eyes and took possession of me. In 1990 I became the leader of the Holy Trinity church choir and a year later started working as a priest. I used to conduct the choir and, seeing the priests baptising and getting people married, I started wishing to do the same. Maybe it happened because the person of Jesus Christ acquired a new concept in my mind, maybe because my uncle is a priest. I started the work at the age of forty, although before I thought I would return to the activity when a pensioneer. (III/23)

The priest emphasized that Christianity is not a philosophy, but a way of life:

Christian life is religious practice following Christ. Faith without deeds is dead. Christ taught his followers that the most important thing in Christianity is love. It makes no difference what Church we talk about: Orthodox, Catholic or Protestant. (III/23)

On the one hand, the parish priests share quite a broad view of Christianity embracing different Christian confessions and accepting different manifestations of their religious identity. On the other hand, parishioners' strong faith and respect for the church ministers inspire the priests to look for new forms of evangelization and of the expression of religious identity, such as concerts of Church music, free piano lessons for poor parish children, various means of education, and pilgrimages to different religious sites. 


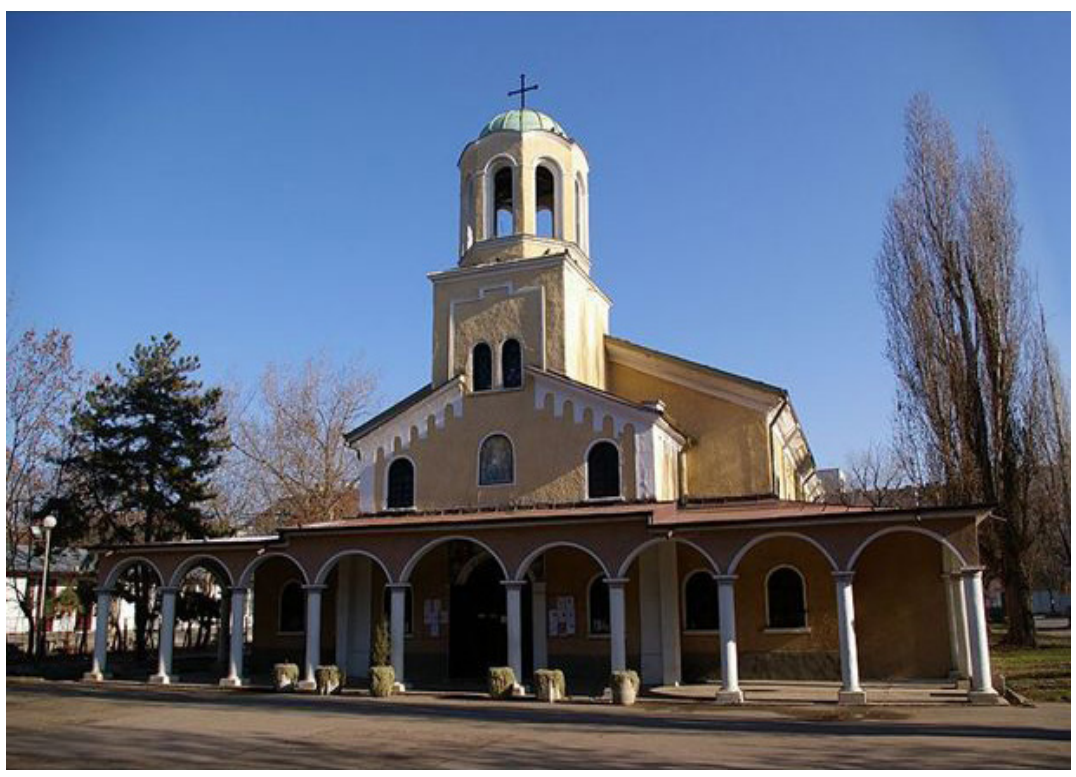

Figure 1. The Bulgarian Orthodox Church of the Holy Trinity in Sofia. Photographer unknown. Source: http://www.hramove.bg/hramove/temple_45.html, last accessed on 19.02.2021.

\section{The Bulgarian Greek Catholic Church}

The Catholic Church is the fourth largest religion in Bulgaria after Bulgarian Orthodoxy, Islam and Protestantism. According to the latest national census of the Bulgarian Republic, held in 2011, 48,945 citizens ( 0.7 per cent of the population of 7 million) identified themselves as Catholics (NSI 2011). According to the statistics of the Eastern Catholic Churches, 'The Apostolic Exarchate of Sofia had 10,000 Catholics in 16 parishes, cared for by 1 bishop, 1 seminarian', 13 religious priests and 4 secular priests, with 15 other monks and 27 nunsin 2017 (ECCS 2017: 8).

Historically, after the Great Schism in the Christian Church of 1054, the Christian world was divided between the Eastern (Orthodox) churches and the Western (Catholic) churches. The main dividing issue was a dispute over recognition of the Roman Pope as Head of the Church and of his authority. The Western Church, the Roman Catholic Church, claimed that the pope's re- 
ligious authority over Christians was universal. The Eastern Church, known as the Eastern Orthodox Church, disagreed, in their case investing their highest religious authority in various patriarchs across the Eastern Orthodox world, with the ecumenical patriarch of Constantinople traditionally holding the title "first among equals" (PER 2017a).

The Catholic Church in Bulgaria consists of two components: the Western (Roman or Latin) Church and the Eastern (Byzantine/Greek) Church. The Bulgarian Greek Catholic Church is a Byzantine rite Church in full union with the Catholic Church. It falls 'under the direction of the Vatican dicastery, known as the Congregation for the Eastern Churches, whose head is chosen by the pope' (Hafkes-Teeples 2008: 28). It accepts the Roman Catholic faith, keeps the seven sacraments, recognizes the pope as head of the church, but retains all other characteristics of the Byzantine rite: 'liturgy, spirituality, sacred art, and especially organization' (EB 2021).

The second case study in my research for this paper is the parish of the Cathedral bearing the title of the Assumption of the Blessed Virgin Mary (see Figs. 2-3). It was built in 1924 in order to meet the religious needs of Easternrite Catholics in Sofia. Two years later, in 1926, an Apostolic Exarchate was established in Sofia with the support of Archbishop Angelo Roncalli, the future Pope John XXIII, who was Apostolic Visitor in 1925-1931 and later the Apostolic Delegate (1931-1934) to Bulgaria. Archbishop Roncalli also supported the opening of an inter-faith seminary in Sofia in 1934, which was conducted by Jesuit monks until 1945, when it was closed (Roberson 2008).

In 1941, the Uniate or Bulgarian Greek Catholic Church parishes came under the jurisdiction of the Apostolic Exarchate in Sofia. Despite this the Church was not officially suppressed in Soviet-era Bulgaria, but it had to function with numerous restrictions. The Bulgarian Greek Catholic Church especially suffered repression in the early years of communist rule. A large number of priests were imprisoned, and the Byzantine Catholic bishop died under mysterious circumstances in 1951 (Roberson 2008).

The inhabitants of Sofia remember that in Soviet times, when people were arrested, one Uniate church avoided outright repression. The parish of the Cathedral of the Assumption of the Blessed Virgin Mary was turned into a battlefield. One Bulgarian woman remembered this difficult period of parish life as follows: 
In the evening the officers of the forces of repression used to come to this church and conduct a search. They had weapons which they would leave in the church. Guns were hidden under the altar. In the morning they would return for another search and would arrest the 'guilty' priests. At noon people would look out of their windows and see a noisy 'theatrical show' being made of taking weapons away. They did their best to provoke press comments with sentences announced in the newspapers, followed by short films about the events. Uniate parishioners were scared of repression. Therefore they chose to go to the Roman Catholic church, where they felt more at ease. Also, some Roman Catholics went to their church to pray in order to support the parishioners of the Uniate church (II/9-10).

Psychologists emphasize that 'religious groups are promoted to create a friendly environment for integration and support of their own members' (Giorgadze et al. 2017: 77). In such circumstances the support of the members of different confessional groups was very important, because it helped them create closer social networks and interconfessional links in what was a precarious society suffused by Soviet atheist propaganda.

Today, since the fall of the Soviet Union, the Bulgarian Catholic Church of the Eastern rite is on good terms with the Roman Catholic Church of the Latin rite. The priests of both churches quite often celebrate Mass together or substitute for each other in case of need. In the evening they pray the rosary together with the Roman Catholics of the Latin rite. The monks of both rites also have meetings together. The Cathedral of the Assumption of the Blessed Virgin Mary is assisted by sisters of the religious order of the Holy Eucharist, that is, by Carmelites who live in the outskirts of Sofia, about (seven km away.

Today the parish of the Assumption of the Blessed Virgin Mary hosts 3000 believers, though not all of them attend church. On Sundays some 100200 people take part in the liturgy, mostly Bulgarians, but also Ukrainians, Romanians and those who were originally Macedonians. Often the members of the parish are closely connected with the identity of the ethnic group they have been closest to since childhood. In these cases ordinary lay people have a stronger sense of the church beeing truly theirs (Hafkes-Teeples 2008: 19).

Some believers attend Holy Mass every day and are engaged in worshipping the Holy Sacrament. Some young people attend morning Mass on their way to work and commit themselves to attend church on a special day for nine months 
in turn. Although they belong to the Church of the Eastern rite, some of them seek spiritual guidance from Roman Catholic priests and attend charismatic prayer schools, such as Mary's school. Such movements allow young Christians to share their spiritual experiences and to enter into deeper relation with God. One young female parishioner stated:

I had adevotion to the sacred Heart of Jesus. It is closely connected with the Eucharist. I decided to go to Holy Mass every day. Six years ago Carmelites changed the direction of my spiritual life so that I had a closer relationship with God. At first, I suffered for two or three years, but God helped me to change. The Eucharist is of great help. (III/ 4)

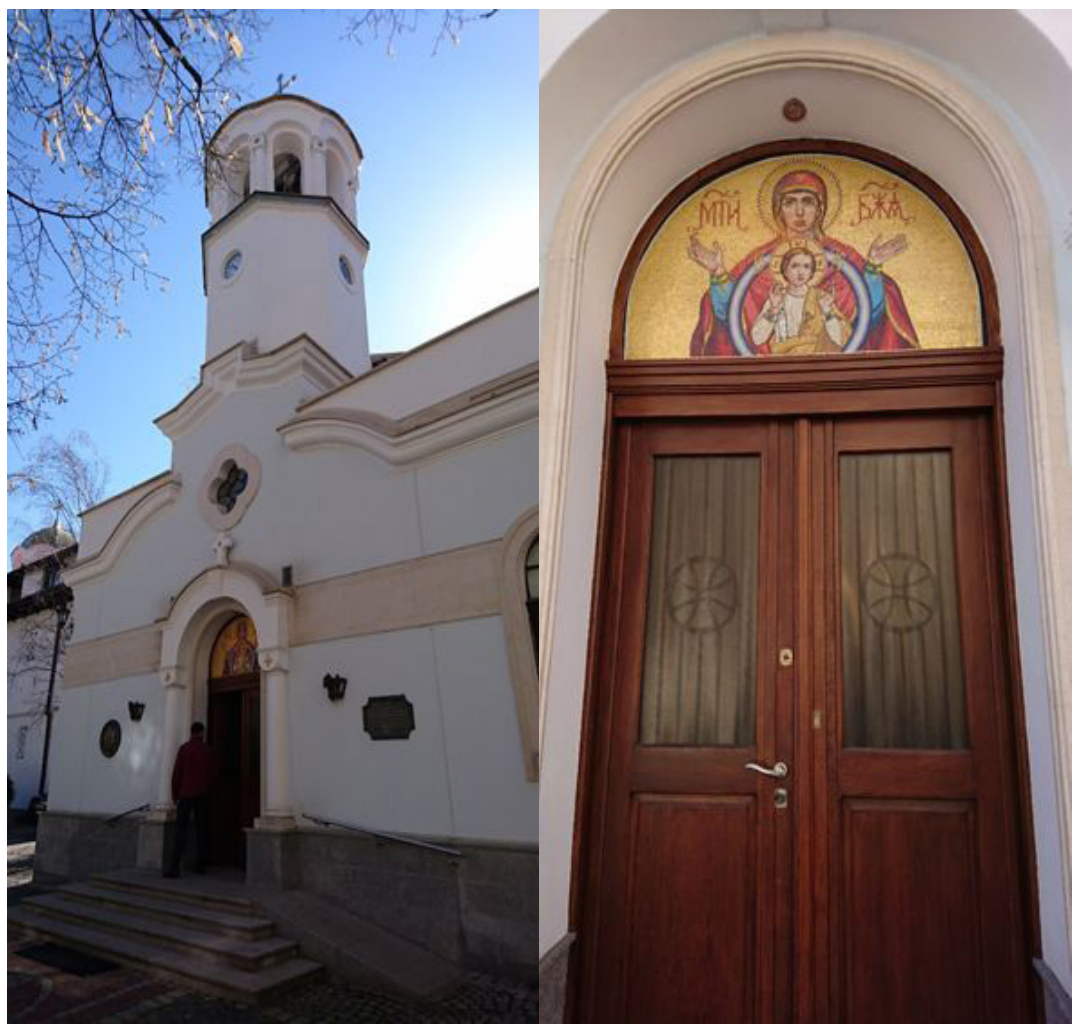

Figures 2, 3. The Cathedral of the Assumption of the Blessed Virgin Mary in Sofia. Photos by Rasa Račiūnaitè-Paužuolienè 2017 
This religious involvement and a deep relationship with God is associated with deeper inner peace. Religious involvement enables the individual to avoid emotional or physical crises, 'especially when a person suffers a heavy loss during serious illness or as a result of death of the beloved ones' (Giorgadze et al. 2017: 77).

Since Soviet times, the Eastern (Byzantine) Church has been deeply affected by the process of secularization, whose negative results are seen in the decline in sacramental practice. The annual statistics of the parish reveal six or seven weddings, twenty baptisms and fifteen to twenty funerals. During the period of change, from 1989, there used to be 120-150 baptisms every year (II/16-19). The secularization of Bulgarian society is related to the growing spread of neoliberal ideas and increasing individualistic practices. According to the parish priest:

Today cohabitation is wide spread in Bulgaria. People do not get married in church nor register their marriages officially, making the excuse that weddings are costly events. In Soviet times very few people lived together unmarried - the state did not tolerate cohabitation. (II/16-19)

In Soviet times the Catholic priests of the Eastern rite could choose to get married, but at present it is no longer the custom. Nowadays priests and parishioners are engaged in social activities, such as taking care of the disabled. In 2017 members of both Churches organized a journey to Fatima in Portugal with the participation of 250 pilgrims.

The Bulgarian Catholic Church of the Eastern rite has a profound liturgical tradition. The iconostasis and liturgy of the Church of the Eastern rite is similar to that of the Orthodox Church, though the prayers and some festivals are identical to those in the Catholic church of the Latin rite. The believers pray the rosary not only at home with family members, but also before every Mass. The service of the Church is unimaginable without icons, as they contain pictures of Christ and the saints: 'they are kept at hand and handled with loving gentleness' (Hafkes-Teeples 2008: 19).

The Bulgarian Catholic Church of the Eastern rite and the Bulgarian Orthodox Church have the same rite, one that differs from that of the Latin Cchurch. For instance, the Orthodox Church allows childen under the age of seven to receive the Holy Communion without any preparation, while the Uniate church has no such tradition. Children are prepared for the sacrament of the Holy Communion by cathechists and nuns, while adults are assisted by 
priests (II, 16-19). About 95 per cent of festivals coincide with those celebrated in the Orthodox Church, for example, the feast of circumcision, celebrated on January 1. On March 25 believers take flowers to the icon of the Blessed Virgin Mary and kiss it, although this is not a strict rule.

The priest of the Bulgarian Greek Catholic Church of Sofia pointed out that some traditions are closely connected with the liturgy. People follow the tradition of taking grapes to liturgical celebrations, especially when celebrating Jesus' transfiguration on August 6. They say a special prayer asking for a successful harvest, and country people living in mountainous areas bring grapes to give thanks for a good vintage. Town dwellers buy grapes in grocery stores. (II/ 8)

The tradition of taking grapes to liturgical celebrations has been followed not only in the Bulgarian Catholic Church of the Eastern rite, but also in the Bulgarian Orthodox Church. It is popular not only with the rural population, but also among city-dwellers.

In conclusion, the Bulgarian Catholic church of the Eastern rite is distinguished by its great liturgical and spiritual tradition. 'Theology in the East tends to focus on relationships - God and the believer, the individual believer and the Church community, and so on' (Hafkes-Teeples 2008: 21).

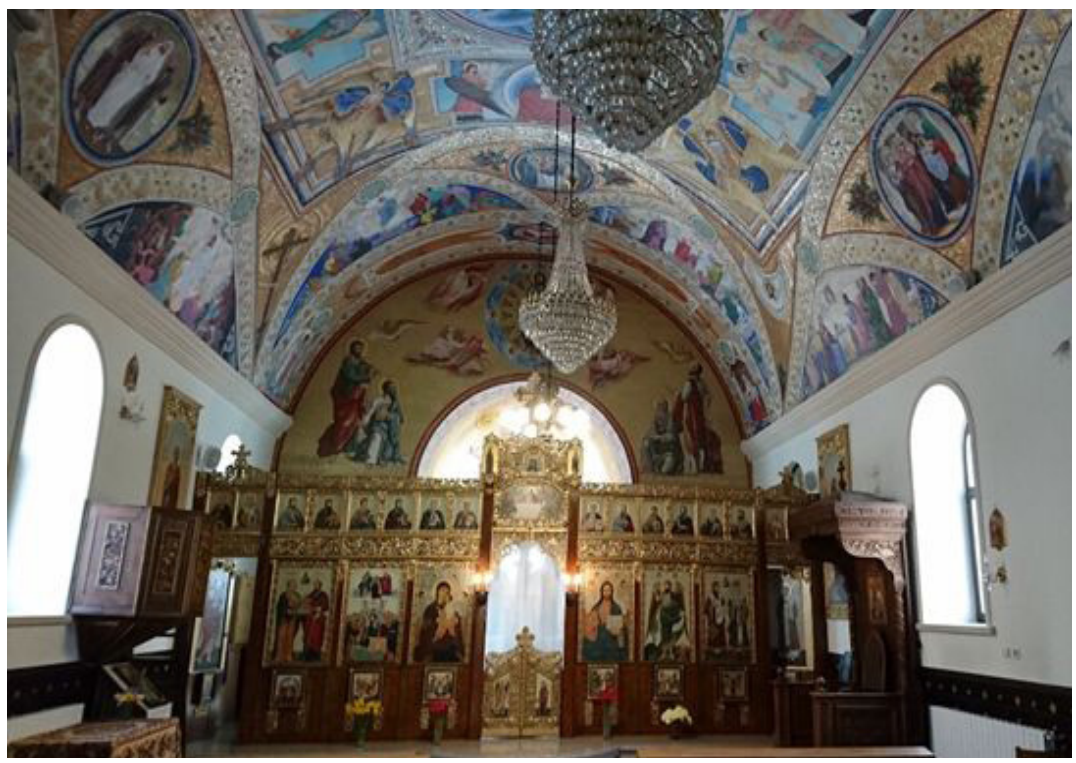

Figure 4. The interior of the Cathedral of the Assumption of the Blessed Virgin Mary in Sofia. Photo by Rasa Račiūnaitè-Paužuoliene 2017. 


\section{The Roman Catholic Church}

The last object of my research is the Roman Catholic Church. Today Roman Catholics live in the larger cities, such as Plovdiv, Sofia, Ruse, Varna and Burgas, and villages in southern and northern Bulgaria. The largest concentration of Catholics live in Plovdiv and the surrounding area.

The Catholic Church has deep roots in Bulgaria, extending back to the baptism of country in the ninth century, which was followed by a short-lived union between the Bulgarian and Roman Churches under King Kaloyan in the early thirteenth century.

Catholicism in Bulgaria is linked to the missionary activities of Catholic orders and congregations, such as the Passionists, Capuchins, Franciscans, the Resurrectionists, Assumpsionists, Benedictines and others who have come from Bosnia, Italy, France or Poland (Koinova 1999b). Between 1878 and 1944, many new missionaries arrived in Bulgaria. New churches, Catholic schools and colleges were built. Catholic orders and congregations organized some schools in Bulgaria, the most active being the French and Italian orders. 'According to data of the late 1920s, the French Catholic schools were based in six major towns of Bulgaria - Plovdiv, Sofia, Bourgas [Burgas], Yambol, Rouse [Ruse] and Varna, and were separated for males and females' (Zaimova et al. 1992: 295-8, cited in Koinova 1999b: 26). The most famous of them "were the "St. Augustinus" college in Plovdiv, the schools for females of the "St. Joseph" sisters in Sofia, Plovdiv and Bourgas and of the Assumpsionist sisters in Varna and Yambol, as well as the college for boys of the "Brothers of the Christians Schools" in Sofia" (Assenov 1998: 129; also Koinova 1999b: 26). Catholic shools and colleges delivered a high-class education and were much appreciated. Also the Catholic Church had four small seminaries for Catholic priests. Catholic education was interrupted in the period from 1944 to 1989. The French Catholic colleges were closed down in the late 1940s. 'While the very limited numbers of Orthodox clerics continued to be educated in the higher education Orthodox seminary in Sofia, Catholicism was not taught at all. [...] In 1989 there were only about 40 Catholic clerics in Bulgaria' (Assenov 1998: 135; also Koinova 1999b: 27).

During the communist regime (1944-1989) Bulgaria entered the sphere of political influence of the Soviet Union. 'With its doctrinal atheism, communism declared religion harmful to the development of a new socialist identity, based on the cleavage of the social classes' (Koinova 1999b: 9). The main goal of the 
communist regime was to destroy its most influential bishops and priests, who opposed the sovietization of Bulgaria and the removal of religion from the public sphere (Chureshki 2004; Kalkandjieva 2011: 140). All religions, including the Orthodox Church, a traditional presence in Bulgaria, suffered restrictions on their activities, including the closure of religious schools, newspapers and other religious organizations, but the Catholic Church suffered more than the Orthodox Church (Koinova 1999b: 9). The fact that Bulgarian Orthodox Church, like the Muslim denomination's officers, received state pensions, and that their clerics received subsidies from the state (Koinova 1999b: 11), demonstrated their particular loyalty to the regime. On the other hand, it also shows discrimination against the Catholic Church.

The Catholic and Protestant Church 'were persecuted not only as religious institutions but also as spies of Western Imperialism. They [...] were presented as enemies of the Bulgarian nation in the past or [as] instruments of anti-communist propaganda' (Kalkandjieva 2011: 144). This negative attitude towards the Catholic Church was particularly strong in the first years of communism. Historical studies of religion published in Bulgaria under the communist regime were also marked by Soviet-style propaganda and atheistic ideology. 'This created a distorted picture of Bulgaria's religious history, overemphasising the role of the Orthodox Church at the expense of the other religious communities considered as alien to society' (ibid.).

Between 1944 and 1949, Catholics experienced a lot of jail sentences. All the Catholic Church's real estate, lands, schools, colleges, and hospitals were expropriated in 1948 under the Collectivization Law. All the Church's social and educational institutions were closed and monopolized by the state, depriving priests and the religious of their main sources of income (Koinova 1999b: 11). One 1st March 1949, a new law was passed whereby all expatriate clergy and religious individuals were expelled from the country. This affected the Latin-rite Church much more than the Eastern-rite Church (Brown 1983: 312).

However, the formal restrictions on the Catholics did not satisfy the totalitarian regime. At that time, all the churches suffered brutal persecution. According to Janice Brown, there were one hundred and twenty arrests of Catholic clergy and laity (Brown 1983: 312). In September-October 1952 the regime held a series of fabricated trials against some 55 Catholic clerics (Koinova 199b:12). Twenty six priests, two sisters and eleven members of the laity were accused of a wide range of crimes, and four members of the clergy 
were condemned to death (ibid.). Among them was Dr Eugene Bossilkov, Bishop of Nikopolis, 'generally regarded as the most energetic of the bishops and the one who could have been the focus of resistance' (ibid.). He was shot a few days after the trial, on 3 October 1952, but the Vatican did not learn the facts of his death until 1975. In August 1952, the arrested clerics and other Catholics numbered seventy (Tsvetkov, 1994:34; citated from Koinova 199b:12). Many of them were sent to jail for between ten and fifteen years, while others were sent to communist concentration camps (Tsvetkov 1994: 103-4, cited in Koinova 1999b:12).

Between 1944 and 1989, the totalitarian regime banned all religions due to its doctrinal atheism, but Catholicism suffered even more than the traditional Bulgarian Orthodox Church. According M. Koinova, 'Control over the Catholic Church was impossible first of all because Catholic clerics refused to collaborate with the regime, and second, because the regime did not have the political means to control a denomination subordinated to its center in Rome' (Koinova 1999b: 31).

I now focus on the Roman Catholic parish of St. Joseph, which is the part of the Diocese of Sofia and Plovdiv. According to the statistics of the Eastern Catholic Churches, in 2017 'the Apostolic Exarchate of Sofia had some 10,000 Catholics in 16 parishes, cared for by 1 bishop, 1 seminarian, 4 secular priests and 13 religious priests, with 15 monks and 27 nuns' (ECCS 2017: 8).

The co-cathedral of St. Joseph is located in Sofia's old town, opposite the ruins of ancient Serdica. Its long and complex history started in 1875 . The incentive for increasing the number of parishes were foreign Catholics (Croatians, Germans, Austrians, the French) visiting the Bulgarian capital. During World War II the Cathedral of Saint Joseph suffered from Allied bombing raid and was destroyed. The cathedral was rebuilt only sixty years later, in 2006.

The parish of St. Joseph can be described as the religious, pastoral and cultural centre of Roman Catholics in Sofia. The parish is very active, composed of Catholics belonging to different ethnic groups (Bulgarians, Croats, Poles, Italians, French, Romanians, and others). Nowadays about seven hundred Catholics attend Holy Mass at the St. Joseph Co-cathedral every week. Sunday service attracts around one hundred parishioners, ranging from regular Bulgarians to foreign diplomats speaking different languages. Its multicultural and multilingual character singles the parish out among other Bulgarian parishes. While the church is attended by 80 per cent of Bulgarians, its members include 
foreigners (Poles, Croats, Austrians, French, Italians, Romanians, Arabs, Filipinos, Lebanese, Vietnamese), those who come from different backgrounds and make different contributions (Račiūnaitè-Paužuolienė 2018). Some communities, e.g., the French, include elements characteristic of the liturgy celebrated in their own country. Members of the Italian community prefer the midday Latin Mass, while the Polish community attends the Polish-language service, which incorporates distinctive elements of the Polish liturgy.

Parish life is enlivened by organ concerts, and its catechism course, which run for two or three years, enjoy great popularity among adult parishioners. Besides, the parish organises piligrimages to various sacred places in Bulgaria. Catholics in Bulgaria have a longstanding tradition of celebrating the Marian feast in May in the mountains, where they celebrate Holy Mass, pray the rosary, and sing chants and litanies venerating God's Mother. Also, the parishioners have a tradition of participating at the Road of the Cross on the hill of Vitosha during Holy Week.

The parish priest, a Polish Capuchin, emphasized the strong faith and moral values of Bulgarian Catholics: 'Every day they attend the Holy Mass and obey the moral rules and ancient traditions. With the help of grandmothers and grandfathers, Bulgarian Catholics saved their faith' (II/3). Thus the commitment and the continuity of traditions and Christian values, and maintaining the religious inheritance and handing it on to new generations, could be enumerated as factors defining the religious identity of Bulgarian Catholics.

The parishioners affirmed that 'catholics consider it is important to maintain their faith and spiritual belonging. Catholic priests are important people in our life. Catholics who had no priests lost their faith and became Orthodox' (II/7).

There are some tragic stories about the level of hostility towards the Catholic Church during the totalitarian regime. As mentioned earlier, a lot of priests, bishops, monks and nuns, as well as members of the laity, were executed for their faith. Most churches and monastaries became empty and were closed. The Catholic Church struggled to survive against these enormous odds. In such conditions, 'faith became the subject of intense pressure by Communist ideology no matter whether the person had inner faith or not' (Giorgadze et al. 2017: 78). Some parishioners recalled this period as follows:

In 1949 the Catholic Church was declared illegal. [Catholic ....] seminaries were closed and there was no possibility to study... Thus Catholics went to 
study in Sofia. There they were allowed to stay for two days, and on the third they had to leave. (II/8)

People were afraid to go to church under the Soviet regime. In the provinces, however, they felt freer. The faithful used to go secretly to church once or twice a year. They started attending it after the political system changed. (II/13)

One Catholic man from the provinces remembered how local Catholics still loyally attended church in his childhood in the 1960s, despite the prevailing atheistic propaganda and the blacklisting of church visitors.

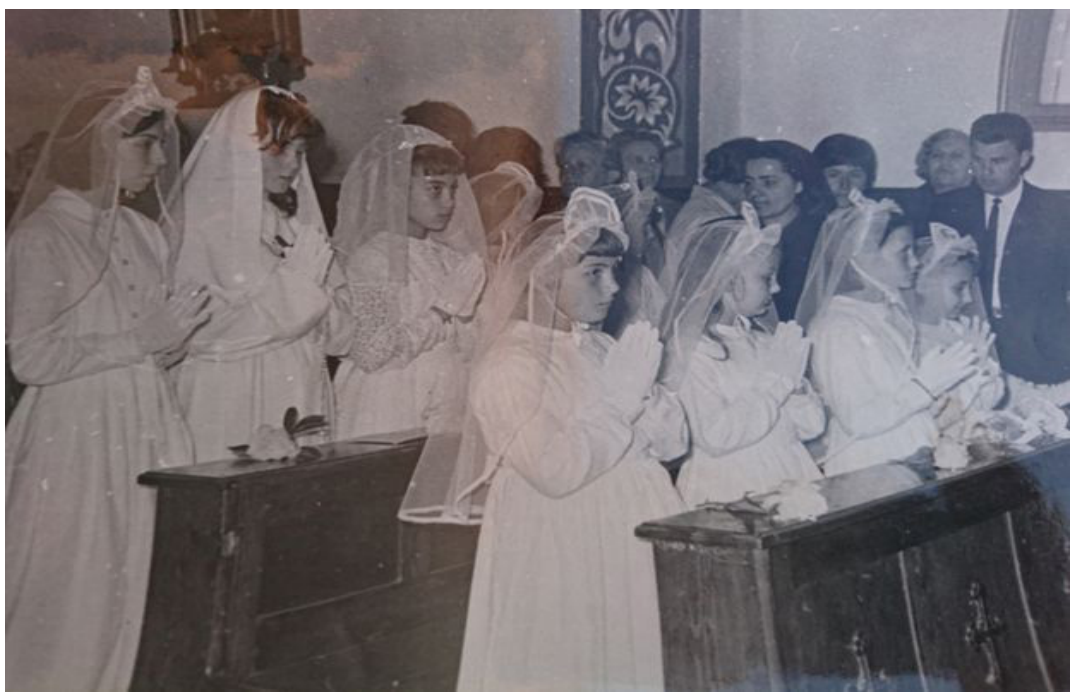

Figure 5. The First Communion at the Roman Catholic parish of St. Joseph in Sofia, 1966. Photographer unknown. 
After the fall of the Soviet Union, when the situation started changing, many Orthodox believers turned to the Catholic Church. One parishioner, a woman, stated:

Perhaps Orthodox priests are not those people would have as their spiritual leaders. In Soviet times they would accept disobedient and not very intelligent candidates. Nowadays the former graduates educate the faithful. 'Ignorance educates ignorance'. People search for true things, they ask lots of questions.

The church of St. Joseph has lots of neocatechists who come from Orthodox families, but are not baptised - their parents were afraid to get married in church and thus to baptise their children. (II/13)

Parishioners from St. Joseph Church emphasized the interfaith relations between Roman Catholics and the Bulgarian Catholics of the Byzantine Tradition:

Spiritually we had close ties with members of the Uniate Church. They used to come to our church. The Uniates enriched our calendar with some saints from the Church of the Roman rite. We prayed the rosary together. The Orthodox have the Acatist, a chanted prayer, which could be compared to the rosary, though it's quite different. (II/9)

Another parishioner, born in Sofia in 1959, who was asked about Bulgarian identity, said that 'First of all, we are Bulgarians, then Christians, and as such we break up into Orthodox and Catholics' (II/1). Her words explain how Bulgarian Christians define their identity: they prioritize their ethnic identity, which is followed by their overall Christian identity and finally their specific confessional identity.

A survey of Catholics reveals that the Catholic community became the site of religious and cultural resistance against the oppressive regime in Bulgaria. In summary, one can agree with J. Brown that 'Bulgarians have a long tradition of resilience, tenacity and resourcefulness under persecution, going back to Turkish times. No group has demonstrated this better than the Catholics' (Brown 1983). 


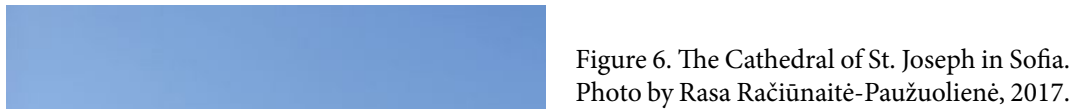

Figure 7. Statue of St. Joseph. The Cathedral of St. Joseph in Sofia. Photo by Rasa RačiūnaitèPaužuolienè 2017

Photo by Rasa Račiūnaitè-Paužuolienè, 2017.
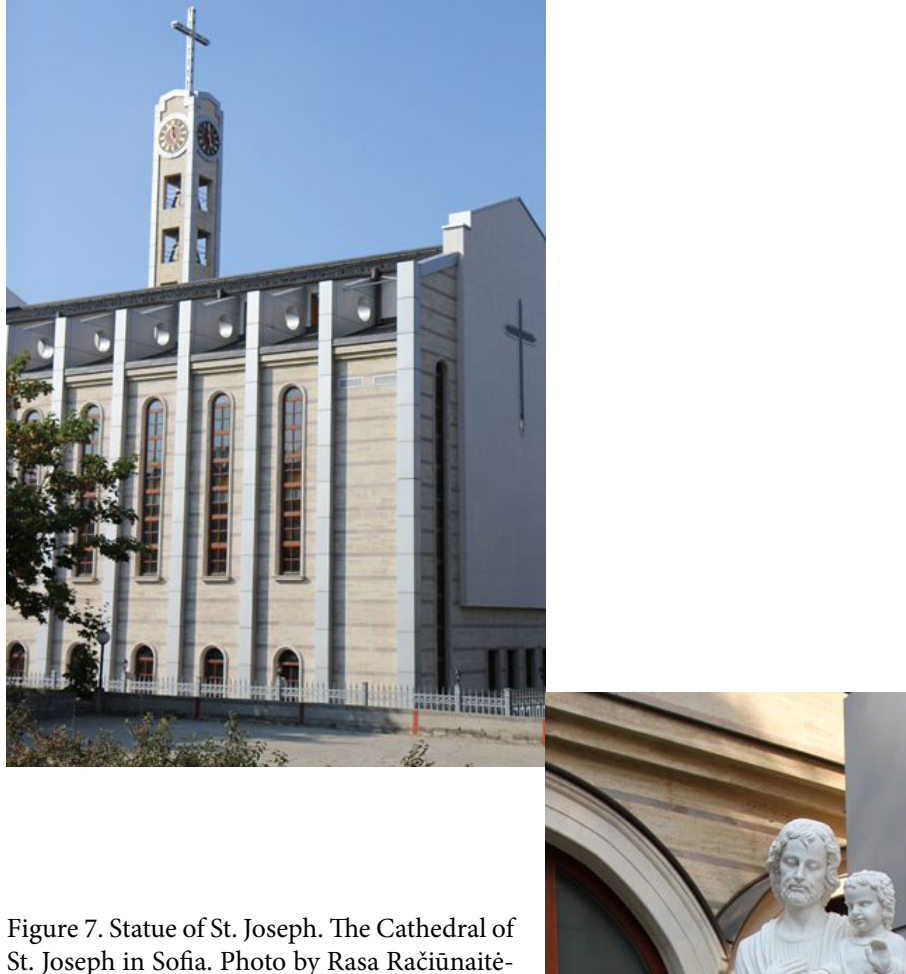


\section{Conclusion}

In this paper, the multiple identities of Bulgarian Christians has been revealed with reference to three different cases. The example from the Bulgarian Orthodox Church shows that Orthodox Christians in Bulgaria more likely to believe in God and identify with Orthodox Christianity than practice their religion. They do not perform religious practices at a high level, so they might be desrcibed as 'believing and belonging, without behaving' (PRC 2017b). The case of the Bulgarian Orthodox Church of the Holy Trinity testifies to the strong faith of the parishioners, as well as their respect for the church's assistants, inspiring priests to look for new forms of evangelization and of the expression of religious identity, such as concerts of sacred church music, pilgrimages, free piano lessons for the poor parish children and various means of education.

The Bulgarian Catholic Church of the Eastern rite is characterised by a profound liturgical and spiritual tradition. During the totalitarian Soviet period members of the Church managed to maintain their religious identities due to their spiritual unity and inter-faith links with the Roman Catholics, who helped to create a friendly environment and close social support networks.

During that period, the religious identity of the Roman Catholics was strengthened by their awareness of repressed priests, clandestine monks, nuns and selfless members of the laity. The modern religious identity of Bulgarian Roman Catholics is related to their everyday commitment, their nourishment of Christian values and the continuity of Church traditions, thus ensuring that this religious inheritance is passed on to younger generations.

In summing up the insights of the research material, it should be emphasized that modern Bulgarian Christians have multiple identities, but prioritize their ethnic identity, following that with their overall religious identity, and ending with their specific confessional identity.

\section{Notes}

${ }^{1}$ For example, only 5 percent of Orthodox Christians in Bulgaria say they attend a service of worship at least weekly, while 21 percent of Orthodox believers in Romania and 12 percent in Ukraine attend such services weekly. (PRC 2017b).

${ }^{2}$ The Pew Research Center (PRC) is a non-partisan fact-finding centre that informs the general public about the issues, attitudes and trends that are shaping the world. It does 
not take policy positions. The Center conducts public opinion polling, demographic research, content analysis and other data-driven social-science research. Available at https://www.pewresearch.org/about/ last accessed 07.11.2021.

${ }^{3}$ Conversation is an ethnographic method with a 'varying degree of formality, from the daily chitchat, which helps maintain rapport and provide knowledge about what is going on, to prolonged interviews...' (Kottak 2010: 49).

${ }^{4}$ The concept catholic originated from the Greek term katholikos, meaning 'universal' or 'general'. It was first applied to the Christians in Smyrna c. 107 by St. Ignatius of Antioch. As a title in Christianity it denotes a characteristic communion and a unity of dogma or doctrine and belief, held by the entire Christian Church in all places and and at all times, as opposed to local usage. 'Applied to the Eastern Churches, Catholic almost always means the Churches in communion with the See of Rome, as opposed to Orthodox or Apostolic Churches not in communion with Rome' (Hafkes-Teeples 2008: 31-2).

${ }^{5}$ The Byzantine Tradition refers to the Christian way of life which originally developed in Constantinople (now Istanbul), capital of the Eastern Roman Empire (often called the Byzantine Empire) from 330 to 1453. This Tradition spread throughout the eastern Mediterranean to eastern Europe, followed by the Orthodox Church, and by many Byzantine Catholic, or Greek Catholic Churches (Hafkes-Teeples 2008: 32).

${ }^{6}$ Dr Eugene Bossilkov, the Bishop of Nikopolis, was beatified by Pope John Paul II on 15 March 1998 as a martyr for the faith. Bosilkov studied in Belgium, Holland and Italy, where he defended a Ph.D. thesis on the History of Bulgaria. He spoke thirteen languages. Bosilkov was very charismatic, much trusted by the common people (Koinova 1999b: 15). His personal friend Tzanov described him as 'highly cultured, kind and generous, a fearless preacher of the truth' (Brown 1983: 319). In 2002 three Assumptionist priests who had been condemned to death together with him were also declared martyrs for the faith.

${ }^{7}$ Author's note: During the period from 1944 to 1989, all four Catholic seminaries were closed in Bulgaria, so Catholicism was not taught at all. Maybe the respondent is referring to an undergound Catholics seminary in Sofia (similar underground Roman Catholic seminary existed in Lithuania during the period of the Soviet Union's totalitarian regime (for more, see Streikus 2002; Streikus et al. 2015).

\section{Acknowledgements}

The present research was carried out in 2019-2021 as part of the bilateral international project on 'Festival and Everyday Culture in Bulgaria and Lithu- 
ania, administered jointly by the Bulgarian Academy of Sciences, Institute of Ethnology and Folklore Studies, and the Ethnographic Museum and Lithuanian Academy of Sciences, Lithuanian Institute of History. I would like to thank all the individuals who were involved in and helped with the research, as well as those who shared their stories in qualitative interviews.

\section{References}

Assenov, Boncho 1998. Religiite i sektite v Bălgarija [Religions and Sects in Bulgaria]. Sofia: Poligraf.

Ballinger, Pamela and Ghodsee, Kristen 2011. Socialist Secularism: Religion, Modernity, and Muslim Women's Emancipation. In: Bulgaria and Yugoslavia, 1945-1991. Aspasia, Vol. 5: 6-27.

Boncheva, Cvetana 2005. Brak i semeistvo pri Balgarite katolitsi v Plovdivsko prez prvata polovina na 20 vek. [Wedding and Family of Bulgarian Catholics from Plovdiv during the First Half of the 20th Century]. Sofia: Mezhdunaroden tsent'r za izuchavane na maltsinstvata i kulturnite vzaimodeistviia.

Boncheva, Cvetana 2006. Religion within the Context of the Marital Bans among the Bulgarian Catholics from the Region of Plovdiv during the First Half of the 20th Century. Ethnologia Bulgarica, Vol. 3: 113-127.

Brown, Janice 1983. Catholics in Bulgaria. Religion, State and Society, Vol. 11 (3): 310320. DOI: 10.1080/09637498308431094.

BOC - Bulgarian Orthodox Church 2020a. In: Official Website of the Holy Synod of the Bulgarian Orthodox Church - Bulgarian Patriarchate. Available at https:// old.bg-patriarshia.bg/en/index.php?file=bpc.xml, last accessed on 06.11.2021.

BOC - History. 2020b. In: Official Website of the Holy Synod of the Bulgarian Orthodox Church - Bulgarian Patriarchate. Available at https://old.bg-patriarshia.bg/en/ index.php?file=history.xml, last accessed on 07.11.2021.

Chureshki, Stefan 2004. Pravoslavieto i komunizmut v Bălgarija, 1944-1960. Sofia: Prosveta.

Davie, Grace 1994. Religion in Britain since 1945: Believing Without Belonging. Oxford: Blackwell.

Dimitrov, Bozhidar 2002. Bulgaria and the Vatican. Sofia: National Museum of Bulgarian Books and Polygraphy Publishing House.

Eade, John 2012. Pilgrimage, the Assumptionists and Catholic Evangelisation in a Changing Europe: Lourdes and Plovdiv, Cargo, Vol. 10 (1-2): 27-46. 
EB - Eastern rite church 2021. In: Britannica, The Editors of Encyclopaedia. "Eastern rite church”. Encyclopedia Britannica, 2021, Available at https://www.britannica. com/topic/Eastern-rite-church, last accessed 16.11.2021

ECCS - The Eastern Catholic Churches Statistics 2017. Source: Annuario Pontificio. Compiled by Ronald G. Roberson, CSP, pp. 1-9. https://cnewa.org/wp-content/ uploads/2020/03/2017-Statistics.pdf, last accessed on 01.09.2020.

Eldărov, Svetlozar 1998. Uniati [Uniats]. In: Krusteva A. Oshnosti i identichnosti v Bălgarija [Communities and Identities in Bulgaria]. Sofia: Petekson.

Eldărov, Svetlozar 2002. Katolicite v Bălgarija (1878-1989): Istorichesko izsledavane. [Catholics in Bulgaria (1878-1989): Historical Research]. Sofia: Meždunaroden Centr po Problemite na Malcinstvata i Kulturnite Vzajmodejstvija.

Ghodsee, Kristen 2009. Symphonic Secularism: Eastern Orthodoxy, Ethnic Identity and Religious Freedoms in Contemporary Bulgaria. Anthropology of East Europe Review, Vol. 27, (2), pp. 227-252.

Giorgadze, K., Shengelia, Ramaz and Durglishvili, Nino 2017. Impact of Orthodox Christian Faith and Spirituality on Society's Mental Health (Based on the Population Survey of Tbilisi, Georgia). Georgian Medical News, Vol. 10 (271): 76-85.

Grozdew, Weronika 2004. National Identity and the Distinctivness of Musical Culture among the Bulgarian Catholic Minority. In: Czekanowska, Anna, Hemetek, Ursula, Lechleitner, Gerda et al. (eds.). Manifold Identities: Studies on Music and Minorities. London: Cambridge Scholars Press, pp. 257-261.

Hafkes-Teeples, Steven 2008. The Eastern Christians and their Churches. New Haven, CT: Knights of Columbus Supreme Council.

Hopkins, James Lindsay 2008. The Bulgarian Orthodox Church: A Socio-Historical Analysis of the Evolving Relationship between Church, Nation, and State in Bulgaria. Boulder, CO: East European Monographs.

Jankov, Angel 2003. Kalendarni prazdnici i obichai na balgarite katolici (kraja na XIX sredata na XX vek) [Calendar Feasts and Customs of Bulgarian Catholics (the End of 19th c. - the Mid 20th c.]. Sofia: Marin Drinov Press.

Kalkandjieva, Daniela 2011. The Study of Religion in Bulgaria: A Challenged Legacy. Interdisciplinary Studies on Central and Eastern Europe. In: Baer, Josette (ed.). From Post-communism toward the Third Millennium Aspects of Political and Economic Development in Eastern and South-Eastern Europe from 2000-2005. Bern: Peter Lang AG, Vol. 7: 125-144.

Kalkandjieva, Daniela 2014. The Bulgarian Orthodox Church at the Crossroads: Between Nationalism and Pluralism. In: Krawchuk, Andrii, and Bremer, Thomas (eds.). Eastern Orthodox Encounters of Identity and Otherness: Values, Self-Reflection, Dialog. New York: Palgrave Macmillan. DOI.org/1057/9781137377388-4. 
Kanev, Petar 2002. Religion in Bulgaria after 1989: Historical and Socio-Cultural Aspects. South-East Europe Review for Labor and Social Affairs, Issue 1: 75-96.

Koinova, Maria 1999a. Ethnic and Religious Minorities in Bulgaria. South-East Europe Review for Labour and Social Affairs, Issue 2: 147-158.

Koinova, Maria 1999b. Minorities in South East Europe: Catholics of Bulgaria. Center for Documentation and Information on Minorities in Europe-Southeast Europe (CEDIME-SE). Report. Available at https://citeseerx.ist.psu.edu/viewdoc/download?doi=10.1.1.693.4612\&rep=rep1\&type=pdf, last accessed on 08.02.2021.

Kottak, Conrad Phillip 2010. Mirror of Humanity: A Concise Introduction to Cultural Anhropology. New York: McGraw Hill.

Liu, Joseph 2005. Believing Without Belonging: Just How Secular Is Europe? Available at https://www.pewforum.org/2005/12/05/believing-without-belonging-justhow-secular-is-europe/, last accessed on 12.02.2021.

Lyubenova, Milena 2018. Traditional Practices and Contemporary Manifestations of the Feast of St. Haralambos Wonderworker in Bulgaria. The Yearbook of Balkan and Baltic Studies, Vol. 1 (1): 77-90. Vilnius-Tartu-Sofia: ELM Scholarly Press. DOI: $10.7592 / Y B B S 1.06$

Monaghan, John and Just, Peter 2000. Social and Cultural Anthopology. A Very Short Introduction. Oxford: Oxford University Press.

Meyendorff, John. 2020. Eastern Orthodoxy: Worship and Sacraments. In: Encyclopedia Britannica. Available at https://www.britannica.com/topic/Eastern-Orthodoxy/ Worship-and-sacraments, last acess on 15.02.2021

NSI - 2011. Population Census - Census results 2011. National Statistical Institute. Republic of Bulgaria. Available at https://censusresults.nsi.bg/Census/Reports/2/2/ R10.aspx, last accessed on 05.02.2021.

Paukštytè-Šaknienè, Rasa 2019. Family Celebrations in Lithuania and Bulgaria: Ethnic, Confessional and Cultural Traits. Yearbook of Balkan and Baltic Studies, Vol. 2: 57-70. Vilnius-Tartu-Sofia: ELM Scholarly Press. DOI: 10.7592/YBBS2.04

PE - 1991. Pulse of Europe: Full Report 1991. Available at https://assets.pewresearch. org/wp-content/uploads/sites/2/2014/01/Pulse-of-Europe-Full-Report.pdf, last accessed on 12.02.2021.

PRC 2017a - Pew Reseach Center, November 8, 2017. Orthodox Christianity in the 21st century. Available at https://www.pewforum.org/2017/11/08/orthodox-christianity-in-the-21st-century/ last accessed on 08.11.2021.

PRC 2017b - Pew Reseach Center, May 10, 2017. Religious Belief and National Belonging in Central and Eastern Europe. In: Pew Reseach Center, May 10, 2017. Available at https://www.pewforum.org/2017/05/10/religious-belief-and-national-belonging-in-central-and-eastern-europe/\#fn-27936-2, last accessed on 10.02.2021. Račiūnaitè-Paužuolienè, Rasa 2011. Tradicijos ir modernumo paralelès bulgarų ir lietuvių vestuvèse [The Parallels between Tradition and Modernity in Bulgarians 
and Lithuanians Weddings], Res Humanitariae. Vol. 9. Klaipėda: Klaipèdos universiteto leidykla, pp. 30-49.

Račiūnaitè-Paužuolienè, Rasa 2018. Religious identity of Bulgarian Catholics' Communities. The Yearbook of Balkan and Baltic Studies, Vol. 1 (1): 31-44. VilniusTartu-Sofia: ELM Scholarly Press. DOI: 10.7592/YBBS1.03.

Roberson, Ronald 2008. The Eastern Christian Churches: A Brief Survey (7th Edition). University Press of the Pontifical Oriental Institute. In: SNEWA (Catholic Near East Welfare Association of Southern California) website. Available at https:// cnewa.org/eastern-christian-churches/toc/, last accessed on 10.01.2021.

Serafimova, Maria 2011. Religion is a Support for Social Solidarity. Statistics. National Statistical Institute, Republic of Bulgaria, Nos. 3-4: 114-124.

Slavov, Atanas 2020. From Traditional to Official Religion: The Legal Status of the Bulgarian Orthodox Church after 2019. Occasional Papers on Religion in Eastern Europe, Vol. 40 (5): 9-27.

Streikus, Arūnas 2002. Sovietu valdžios antibažnytine politika Lietuvoje (1944-1990). [The Soviet anti-Church Policy in Lithuania in 1944-1990]. Vilnius: Lietuvos gyventojų genocido ir rezistencijos tyrimo centras.

Streikus, Arūnas, Kuzmickaitè, Daiva. K. and Šimkūnas, Vidmantas 2015. Iš sovietinès patirties i laisvès erdvę: Vienuolijos Lietuvoje XX a. antroje puseje. [From the Soviet Experience into the Space of Freedom: Religious Orders in Lithuania in the Second Half of the 20th Century]. Vilnius: Lietuvos gyventoju genocido ir rezistencijos tyrimo centras.

Voas, David and Crockett, Alasdair 2005. Religion in Britain: Neither believing nor belonging. Sociology, Vol. 39 (1): 11-28. London-New Delhi: SAGE. DOI: 10.1177/0038038505048998.

VLE - Visuotine lietuvių eniklopedija 2020. Bulgarijos stačiatikių bažnyčia [Bulgarian Orthodox Church] 2021. Visuotinė lietuvių eniklopedija. Vilnius: Mokslo ir enciklopedijų leidybos institutas. Available at https://www.vle.lt/straipsnis/ bulgarijos-staciatikiu-baznycia/ last accessed on 05.11.2021.

I-IV. Fieldwork materials, written up by the author in Sofia from 2017 to 2020.

Rasa Račiūnaitè-Paužuolienè, $\mathrm{PhD}$, Associate Professor at the Department of Cultural Studies and a chief researcher at Educational Research Institute, Vytautas Magnus University. She is ethnologist and philologist, working in the field of cultural anthropology of the contemporary European society. Her research explores the issues of cultural and religious identity, family and gender studies, the rites of the life cycle, urban and visual anhropology, also migration. 